J. M. MOORE AND I. D. O. FREW: PERIPHERAL VASCULAR LESION IN DIABETES MELLITUS

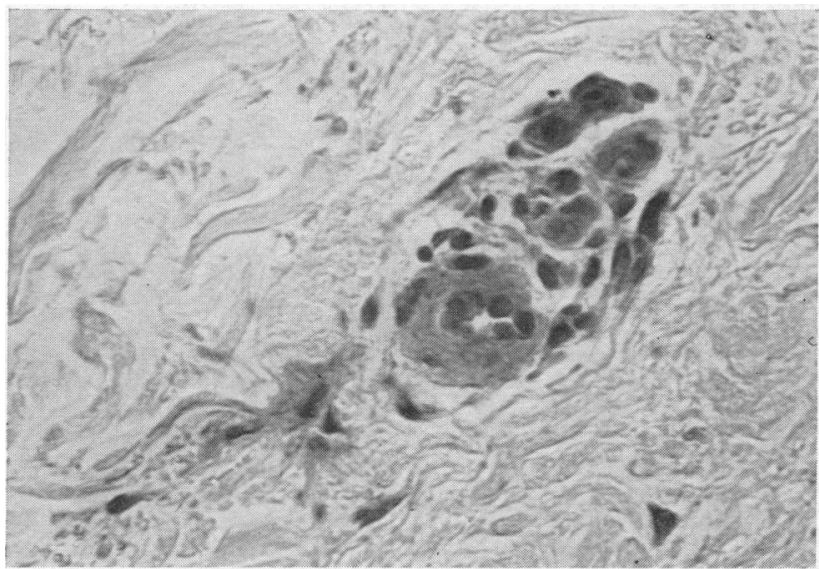

FIG. 1.-Endothelial proliferation and thickening of vessel wall

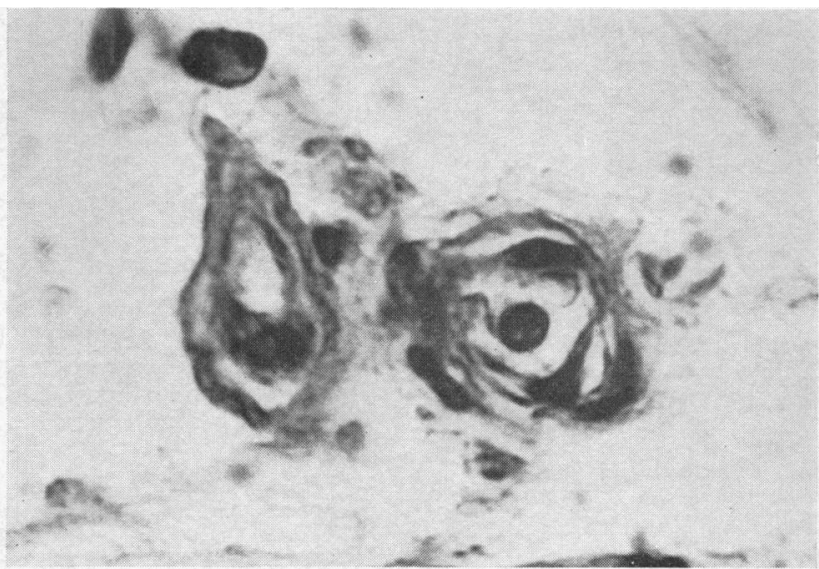
FIG. 2.-Splitting of basement membrane (grade III). (P.A.S.
reaction, green filter. $\times 240$.

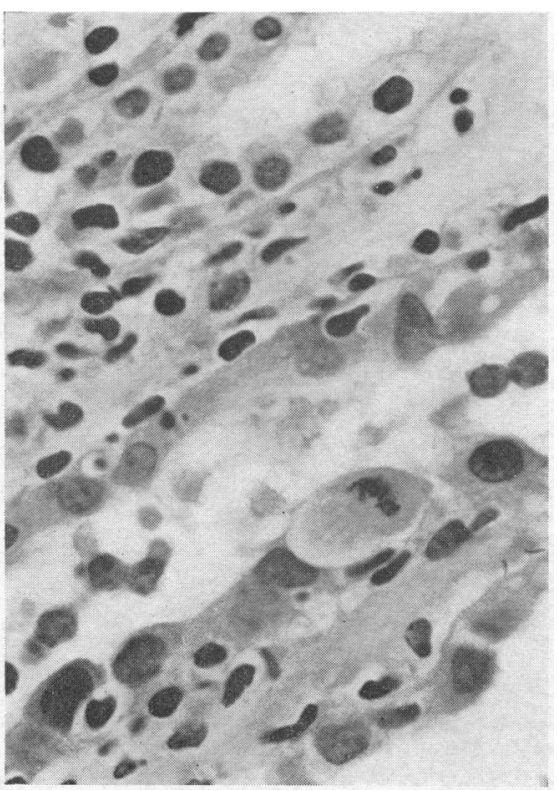

Fig. 1.-Case 1.

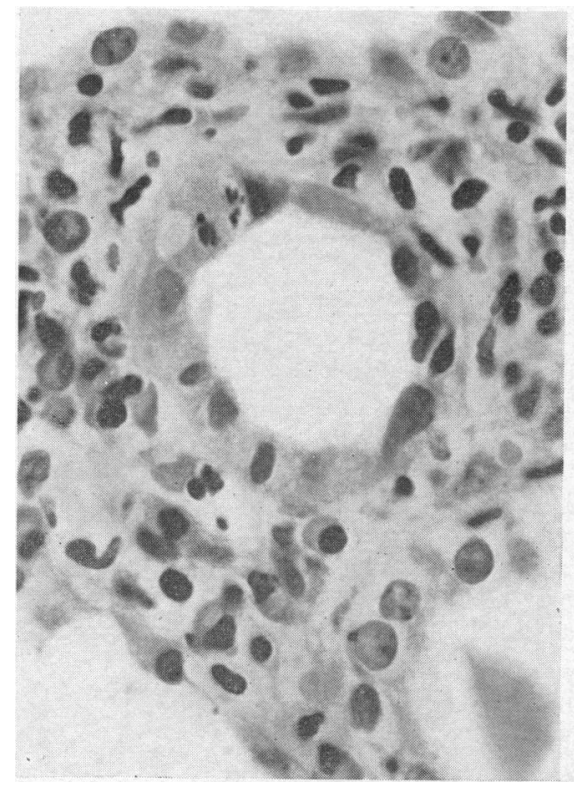

FIG. 1.-Case 5.

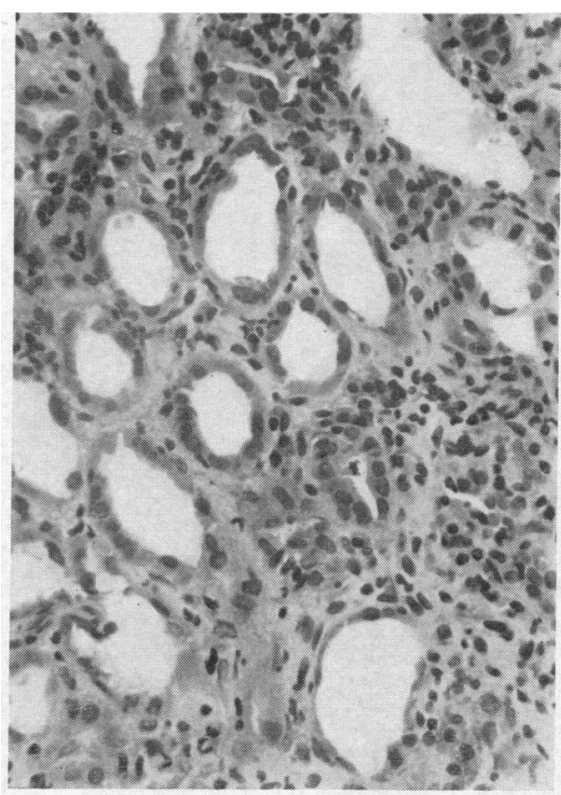

FIG. 2.-Case 1.

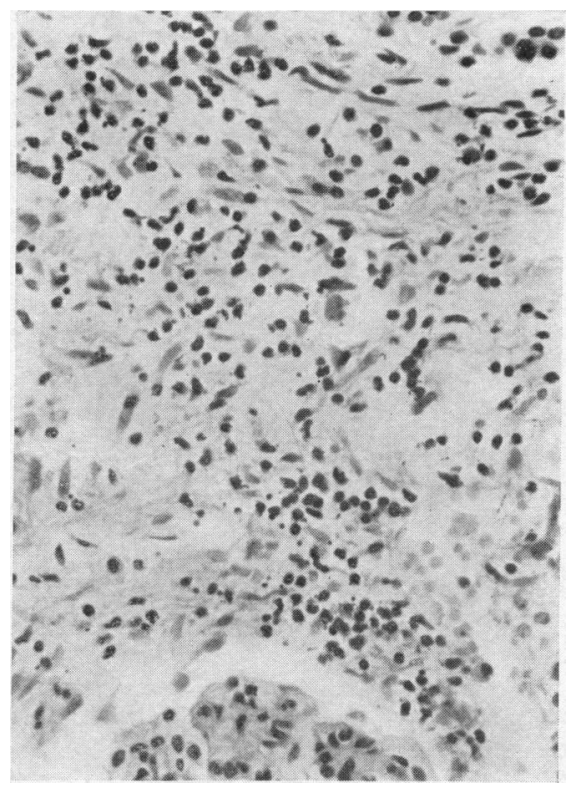

FIg. 2.-Case 4 .

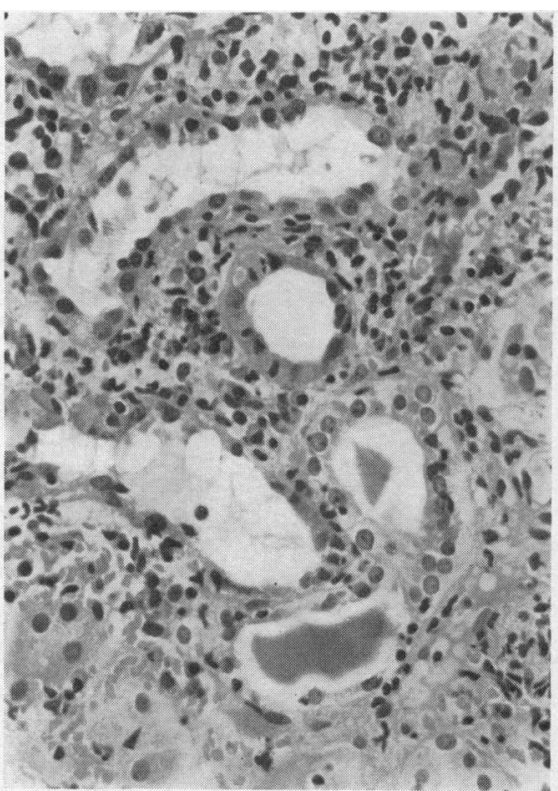

Fig. 2.-Case 5.

FIG. 1-Showing mitotic figures in tubular epithelial cells in Cases 1 and 5 . The interstitial infiltrate can also be seen, and contains plasma cells. (Haematoxylin and eosin. $\times 680$.

FIG. 2.-Lower-power view showing intense interstitial infiltrate in Cases 1 and 5 and some patchy round-cell infiltration in Case 4. (Haematoxylin and eosin. $\times 260$.) 


\title{
Acute Renal Failure in Phenindione Sensitivity
}

\author{
KINSEY SMITH,* M.B., B.SC., M.R.C.P.
}

[With Special Plate]

Brit. med. F., 1965, 2, 24-26

Sensitivity reactions to therapeutic agents are an unwelcome hazard of many forms of medical treatment, although in most cases such reactions involve only the skin and have trivial consequences. Many of the reports of sensitivity to the anticoagulant drug phenindione have been of this kind, but occasionally they have progressed to include life-threatening complications, and this is especially so when acute oliguric renal failure has occurred. Six such cases have been seen in the past five years at this hospital, and are presented here in an attempt to show the nature of the renal lesion and emphasize its clinical course. One of these has previously been reported at a clinicopathological conference, and is one of the six cases of this kind previously reported in the literature.

\section{Case 1}

A 59-year-old man was admitted to hospital with an extensive anteroseptal myocardial infarct in May 1964. He was immediately started on phenindione therapy, and made good progress. Thirtythree days later he suddenly developed an itchy scaling rash around the elbows which rapidly spread over the whole body. He became febrile, and had an eosinophil count of 900/c.mm. Phenindione was stopped, but the rash persisted, and 12 days after its appearance he became oliguric, and was transferred to the renal unit at this hospital because of a rising blood urea. He was a well-built man with a severe scaling eczematous rash over the whole body, but particularly marked over the face and arms. The blood-pressure was $160 / 90$, and there were no signs of heart failure. Apart from slight sacral oedema and acidotic respiration, physical examination revealed nothing abnormal. Investigations showed: blood urea $480 \mathrm{mg} . / 100 \mathrm{ml}$., serum potassium $6.6 \mathrm{mEq} / \mathrm{l}$., and serum bicarbonate $9 \mathrm{mEq} / \mathrm{l}$. Haemoglobin was $12.6 \mathrm{~g} . / 100 \mathrm{ml}$. and whitecell count $10,000 /$ c.mm., with a normal differential pattern. Serum proteins and liver-function tests were normal. Radiographs of chest and abdomen showed slight cardiomegaly and renal outlines of normal shape and size. E.C.G. confirmed the recent myocardial infarction.

Peritoneal dialysis was begun on admission and continued daily for the next 18 days. His urine output remained less than $250 \mathrm{ml}$. daily for a total of 17 days, but he then entered a diuretic phase and peritoneal dialysis was stopped. Renal biopsy on the fourteenth day of oliguria showed striking interstitial oedema and infiltration with eosinophils and plasma cells. There was ample evidence of recovering tubular necrosis, while the 14 glomeruli in the biopsy were normal. Prednisone, $40 \mathrm{mg}$. daily, was started on the eighteenth day of oliguria, and this coincided with the onset of diuresis and a rapid resolution of the skin lesions. His recovery was uneventful with no residual proteinuria, although four months later his blood urea was still $60 \mathrm{mg} . / 100 \mathrm{ml}$.

\section{Case 2}

A previously fit 63-year-old woman had an anterior colporrhaphy for stress incontinence in June 1964. Seven days later phenindione therapy was begun after a pulmonary embolus from a thrombosed deep leg vein. Twenty-seven days later she became febrile and developed a generalized erythematous skin rash. Phenindione was stopped at once, but the rash, after initial improvement, progressed to become a severe and complete exfoliative dermatitis which failed

* Department of Medicine, Postgraduate Medical School, London. to respond to a course of hydrocortisone beginning with $200 \mathrm{mg}$. daily and tailing off completely over 10 days. Two days before this course was completed she became oliguric, passing less than $100 \mathrm{ml}$. of urine daily. The dermatitis was unchanged, and the time between the first appearance of a rash and the onset of oliguria was 20 days. Because of a rising blood urea she was transferred to the renal unit at this hospital.

She was a very ill woman with severe weeping exfoliative dermatitis, most pronounced on the face and neck and with secondary corneal ulceration. The blood-pressure was $150 / 90$ and there was obvious pitting oedema of ankles and sacrum. There was a small right pleural effusion. Physical examination was otherwise normal.

Investigation showed: blood urea $215 \mathrm{mg} . / 100 \mathrm{ml}$., serum potassium $5.2 \mathrm{mEq} / 1$., and bicarbonate $21 \mathrm{mEq} / 1$. Serum proteins were $4.8 \mathrm{~g} . / 100 \mathrm{ml}$. (albumin $2.8 \mathrm{~g}$., globulin $2 \mathrm{~g}$.). Liver-function tests were normal. Haemoglobin was $12 \mathrm{~g} . / 100 \mathrm{ml}$., and W.B.C. was 7,000/c.mm., with a normal differential count. Platelets were $88,000 /$ c.mm. Radiographs of chest and abdomen showed a small right pleural effusion and normal renal outlines.

The day after admission peritoneal dialysis was started. Over the next week her skin improved and her blood urea and electrolytes remained satisfactory in spite of complete anuria. Retrograde ureteric catheterization showed normal collecting systems with no obstruction. After 12 days of complete anuria her urine output rapidly increased to about a litre daily over the next five days, and peritoneal dialysis was stopped. After a further five days, however, her dermatitis again flared up and urine output fell. She was started on hydrocortisone $400 \mathrm{mg}$. daily, but with no response. Three days later she died with severe hypotension and a clinical picture suggesting a Gram-negative septicaemia. Blood cultures at this time were sterile, and she made no response to antibiotics. At necropsy the kidneys showed severe tubular necrosis with no glomerular abnormality. There was no significant interstitial infiltrate.

\section{Case 3}

A 60-year-old man, treated with phenindione following a minor myocardial infarction in October 1963, was allowed to continue with treatment at home two weeks after starting the drug. Twentyfour days after starting phenindione he developed an itchy eczematous rash, facial oedema, swelling of the wrists and ankles, and fever. Phenindione was stopped gradually over the next few days, but the rash became more widespread and he was readmitted to hospital, where treatment with prednisone $20 \mathrm{mg}$. daily was begun. Over the next week, however, his urine output progressively fell to below $300 \mathrm{ml}$. daily, the time between the appearance of the rash and the onset of oliguria being 11 days. He was transferred to the renal unit at this hospital with a rising blood urea.

He was a moderately obese man with an extensive dry eczematous rash, most pronounced in the skin flexures and with cutaneous oedema over the face and arms. Blood-pressure was $160 / 90$. Physical examination was otherwise normal. Investigations showed: blood urea $295 \mathrm{mg} . / 100 \mathrm{ml}$., serum potassium $5 \mathrm{mEq} / \mathrm{l}$, bicarbonate $13 \mathrm{mEq} / \mathrm{l}$. Serum proteins and liver-function tests were normal. Haemoglobin was $10.7 \mathrm{~g} . / 100 \mathrm{ml}$., and the whitecell and platelet counts were normal.

On admission prednisone was continued, but at an increased dose of $60 \mathrm{mg}$. daily. His urine output was $400 \mathrm{ml}$. on the first day, but thereafter he entered a diuretic phase with rapid resolution of the eczema. The highest blood urea was $315 \mathrm{mg} . / 100 \mathrm{ml}$. and the total period of oliguria (urine output less than $400 \mathrm{ml} . /$ day) was five days. A trace of protein was present in the urine on admission, but none was found on discharge. 


\section{Case 4}

A 55-year-old man was treated with phenindione following a severe myocardial infarction in July 1961. Three days later a short course of penicillin was given for a chest infection. Twenty-four days after starting phenindione he developed a generalized red itchy macular rash and the drug was stopped, but the rash rapidly progressed to become a severe exfoliative dermatitis with oedema of the face and neck. Penicillin was given for a further two days, but by then the rash was already extensive and at its most florid stage, with eosinophils comprising $23 \%$ of the total white-cell count. He was treated with prednisone $30 \mathrm{mg}$. daily at this time, the dose being tailed off altogether over 10 days. Eighteen days after the first appearance of the rash his urine output suddenly fell to below $100 \mathrm{ml}$. daily, and five days later he was referred to this hospital with a rising blood urea.

Examination revealed generalized exfoliative dermatitis and acidotic breathing. There was moderate sacral oedema, and crepitations were heard at both lung bases. Blood-pressure was 90/60, and there was a soft apical systolic murmur.

Investigations showed a blood urea of $335 \mathrm{mg} . / 100 \mathrm{ml}$., serum potassium $4.2 \mathrm{mEq} / 1$., and bicarbonate $18 \mathrm{mEq} / 1$. Serum albumin was $2.5 \mathrm{~g} . / 100 \mathrm{ml}$. and globulin $1.5 \mathrm{~g} . / 100 \mathrm{ml}$. E.C.G. showed signs of anterior myocardial infarction, while an abdominal radiograph revealed normal renal outlines.

During the eight days of his admission he passed in all only $250 \mathrm{ml}$. of urine, and was haemodialysed on two occasions. After the second dialysis he developed a septicaemia due to Pseudomonas pyocyanea, and died with severe hypotension.

At necropsy the kidneys showed some post-mortem autolysis, but there was evidence of severe tubular necrosis with some interstitial infiltrate and normal glomeruli.

\section{Case 5}

This case has already been fully recorded at a clinicopathological conference (Postgraduate Medical School of London, 1960). In summary, he was a 41-year-old man treated with phenindione for severe pulmonary hypertension on a basis of thromboembolic disease. Eight weeks after starting this drug he developed fever and an erythematous rash over the trunk and limbs. Four days later he developed oliguric renal failure, and was transferred to this hospital.

After 18 days he entered the diuretic phase-haemodialysis being required in this period-but died of a further major pulmonary embolus.

A renal biopsy on the twelfth day of oliguria showed heavy interstitial oedema and infiltration and severe tubular necrosis. The glomeruli were normal.

\section{Case 6}

A 49-year-old man had an osteotomy of the right hip for osteoarthritis in September 1962, and was treated with prophylactic phenindione in the post-operative period. The operation and anaesthesia had been quite uncomplicated, but in spite of the anticoagulant therapy a deep venous thrombosis occurred in the right leg nine days later. Eleven days after starting phenindione he became jaundiced, and the drug was stopped. The serum bilirubin rose to a maximum of $7.2 \mathrm{mg} . / 100 \mathrm{ml}$. over the next week, but three days after the jaundice was first noted he developed oliguric renal failure, and was transferred to this hospital for further management (under Professor R. Shackman).

He was an ill-looking jaundiced man with a well-healed operation site. There was no evidence of past or present skin rash. He had acidotic respiration, and there was a marked uraemic fetor. Bloodpressure was 160/100. Neither liver nor spleen was palpable.

Investigations showed blood urea $675 \mathrm{mg} . / 100 \mathrm{ml}$., serum potassium $7.5 \mathrm{mEq} / 1$, and bicarbonate $15 \mathrm{mEq} / 1$. Serum bilirubin was $4.7 \mathrm{mg} . / 100 \mathrm{ml}$., and alkaline phosphatase $16 \mathrm{King}$-Armstrong units. Liver-function tests, serum transaminases, and prothrombin time were normal. Haemoglobin was $13 \mathrm{~g} . / 100 \mathrm{ml}$. with a normal white-cell count.

He remained oliguric for a total of 15 days, and required three haemodialyses before entering the diuretic phase and making a complete recovery. The jaundice had faded before the diuresis began.

\section{Microscopical Findings}

Biopsy material was available from Cases 1 and 5, and necropsy material from Cases 2 and 4. Two findings were common to all cases: first, glomeruli which were normal to light microscopy; and, second, more or less severe tubular necrosis.

Glomeruli.-There was no evidence of cellular proliferation or membranous thickening in the glomeruli on light microscopy in any of the four cases studied.

Tubules (Special Plate, Fig. 1).-In all cases there was definite evidence of tubular necrosis with variable destruction and disorganization of tubular epithelium and evidence of cellular proliferation shown by mitotic figures in some tubular cells. In Case 2 there was particularly gross tubular destruction and obvious vacuolation of many of the cells.

Interstitial Tissue (Special Plate, Fig. 2).-A very striking feature in Cases 1 and 5 was gross interstitial oedema with wide separation of the tubules and intense cellular infiltration with eosinophils, lymphocytes, and plasma cells (a feature that is not seen in acute tubular necrosis due to other causes). Case 4 showed moderate interstitial round-cell infiltration, but in no way comparable to that in the other two cases. Case 2 showed no significant infiltrate.

\section{Discussion}

Reports of renal involvement in phenindione sensitivity have fallen into two main groups.

First, there are those with obvious evidence of renal damage but without progression to oliguric renal failure. Brooks and Calleja (1960) noted proteinuria with cells and casts in the urine. Tait (1960) described the nephrotic syndrome, and Hollman and Wong (1964) reported heavy proteinuria, although in none of these cases was any histological information obtained. Pearce (1963) records a transient rise in blood urea, while Garnett et al. (1962) have seen terminal uraemia in a patient dying of extremely severe exfoliative dermatitis and granulopenia. Necropsy in this case revealed cellular proliferation in many glomeruli but normal tubules.

The second group are those with severe acute oliguric renal failure which has always occurred some time after the appearance of other manifestations of phenindione sensitivity. These cases have therefore usually developed renal failure after the drug has been stopped. They seem to present a fairly constant clinical picture which has been reported in six previous patients. Galea et al. (1963), Baker and Williams (1963), and Lee and Holden (1964) each described a case with similar histological findings. The most striking feature was gross interstitial oedema and cellular infiltration with plasma cells and eosinophils, but there was evidence of tubular necrosis in each case. Glomerular changes were either absent or very mild. The case reported from the Postgraduate Medical School of London (1960) and included in the present series as Case 5 showed very similar changes. The cases reported by Kirkeby (1954) and Barritt and Jordan (1960) had a comparable clinical course, though the former gives no histological information and the latter describe tubular necrosis but with no further details.

The microscopical findings in the present cases and those previously described were that tubular necrosis occurred in all, and a severe interstitial infiltrate in five out of eight. In only two were mild glomerular changes present, and although glomerular lesions occur in some other hypersensitivity states this is not a major feature in phenindione reactions. Baker and Williams (1963) considered the infiltration with plasma cells and eosinophils to indicate a primary acute interstitial nephritis, though Allen (1962) believes that the tubular cells 
show little evidence of damage in this rather indefinite condition. Lee and Holden supposed that tubular damage was secondary to interstitial infiltration and oedema, but the occurrence of acute tubular necrosis without major infiltrate in Cases 2 and 4 of the present series suggests that this is not necessarily so. It seems possible that the infiltrate and the tubular damage are both independent features of hypersensitivity, and not dependent on one another.

The other reported features of phenindione sensitivity shown by patients with acute renal failure are set out in the Table. Only one patient (Case 6) did not have an obvious skin lesion, but all showed one or more of the signs reviewed by Perkins (1962). In the present cases the time between starting the drug and the first evidence of hypersensitivity ranged from 10 to 56 days, with oliguria appearing between 4 and 21 days later. In all of them oliguria developed after phenindione had been stopped but before the initial sign of hypersensitivity had subsided. This time-scale in the clinical course is much the same in all reported cases. Lee and Holden (1964) and Baker and Williams (1963) produce some evidence that there may be residual renal damage, and in this context it is interesting that of the three survivors from this unit one still has a blood urea of $60 \mathrm{mg} . / 100 \mathrm{ml}$. four months after discharge (Case 1).

\begin{tabular}{|c|c|c|c|c|c|c|}
\hline Case & $\begin{array}{l}\text { Skin } \\
\text { Rash }\end{array}$ & Fever & $\begin{array}{l}\text { Diar- } \\
\text { rhoea }\end{array}$ & $\begin{array}{l}\text { Granu- } \\
\text { lopenia }\end{array}$ & $\begin{array}{l}\text { Jaun- } \\
\text { dice }\end{array}$ & $\begin{array}{c}\text { Eosino- } \\
\text { philia }\end{array}$ \\
\hline  & $\begin{array}{l}+ \\
+ \\
+ \\
+ \\
+ \\
+ \\
+ \\
+ \\
+ \\
+ \\
+\end{array}$ & $\begin{array}{l}+ \\
+ \\
+ \\
+ \\
+ \\
+ \\
+ \\
+ \\
+ \\
+\end{array}$ & $\begin{array}{l}- \\
\overline{-} \\
\pm \\
\overline{-} \\
- \\
+ \\
\overline{+} \\
-\end{array}$ & $\begin{array}{l}- \\
- \\
= \\
= \\
\overline{+} \\
- \\
- \\
=\end{array}$ & $\begin{array}{l}- \\
= \\
= \\
= \\
+ \\
+ \\
\pm \\
=\end{array}$ & $\begin{array}{l}+ \\
- \\
+ \\
+ \\
+ \\
+ \\
- \\
+ \\
+\end{array}$ \\
\hline
\end{tabular}

The possibility that drugs other than phenindione were involved in the sensitivity reaction has been carefully explored, and in only two patients was this at all likely. Short courses of sulphadimidine and Crystamycin (a combination of penicillin and streptomycin) were given in Case 2 at least three weeks before the onset of the rash, and Case 4 received a short course of penicillin 19 days before the rash. In neither instance was any form of sensitivity-testing thought justifiable, but circumstantial evidence is very much in favour of a phenindione reaction.

With regard to treatment, it clearly is important to stop the offending drug at the first definite signs of hypersensitivity. If acute renal failure occurs it may be prolonged, but it is potentially reversible, and therefore some form of dialysis should not be delayed. Corticosteroids were used for three patients, two of whom survived, but it is impossible to give an objective assessment of their value in a situation where spontaneous recovery may occur.

\section{Summary}

Acute oliguric renal failure due to phenindione sensitivity has been seen on six occasions in the past five years in a busy renal unit. In the four cases where histological material was available the underlying renal lesion was a severe tubular necrosis accompanied in two cases by gross interstitial cellular infiltration. Five patients had a severe skin lesion and one had jaundice as the first sign of their hypersensitivity.

I wish to thank Dr. O. M. Wrong and Professor R. Shackman for permission to publish these cases, and Dr. H. K. Weinbren, who kindly reviewed the pathological material.

\section{REFERENCES}

Allen, A. C. (1962). The Kidney, 2nd ed., p. 441. Churchill, London. Baker, S. B. de C., and Williams, R. T. (1963). Brit. med. f., 1, 1655 Barritt, D. W., and Jordan, S. C. (1960). Lancet, 1, 1309.

Brooks, R. H., and Calleja, H. B. (1960). Ann. intern. Med., 52, 706. Galea, E. G., Young, L. N., and Bell, J. R. (1963). Lancet, 1, 920. Garnett, E. S., Pegrum, G. D., and McDonald, S. J. (1962). 'Brit. med. f., 2, 1032 .

Hollman, A., and Wong, H. O. (1964). Ibid., 2, 730.

Kirkeby, K.'(1954). Lancet, 2, 580.

Lee, H. A., and Holden, C. E. A. (1964). Postgrad. med. F., 40, 326.

Pearce, J. M. S. (1963). Lancet, 1, 1158.

Perkins, J. (1962). Ibid., 1, 127.

Postgraduate Medical School of London (1960). Brit. med. F., 2, 1219. Tait, G. B. (1960). Lancet, 2, 1198.

\title{
Case of Renal Tubular Osteomalacia (Dent Type 2) with Later Development of Autonomous Parathyroid Tumours
}

\author{
H. J. GLANVILLE,* M.R.C.S., L.R.C.P., D.PHYS.MED. ; ROSS BLOOM, † F.R.C.S.
}

[With Special Plate]

Brit. med.F., 1965, 2, 26-29

It is now well known that osteomalacia may comprise an important part of a number of different clinical syndromes. Apart from the classical variety due to deficiency of vitamin $D$, there are three main types not always fully separable from each other. The first is the osteomalacia associated with the large group of malabsorption syndromes, which presumably should include that following partial gastrectomy, though the evidence for malabsorption is often minimal. The second is the osteomalacia from renal disease, subdivided into those cases with gross glomerular failure and those without glomerular but with

\footnotetext{
* Consultant in Physical Medicine, Salisbury Group H.M.C.

† Consultant Orthopaedic Surgeon, Bournemouth and East Dorset H.M.C.
}

mainly tubular dysfunctions. The third comprises a motley collection of hereditary and idiopathic osteomalacias which usually demonstrate a lessened renal-tubular phosphate reabsorption as part of the biochemical findings and which could therefore also be classified in the second group.

In an attempt to stress the importance of renal tubular dysfunction as the cause of rickets and osteomalacia Dent (1952) attempted a classification of the various types recognized at that time. The type that he calls Type 2 , in which a renal-tubular reabsorption defect for both phosphate and glucose occurred in the presence of normal glomerular function, is very rare and has not as yet been described in detail but is of considerable theoretical importance where the possible mechanisms of renal tubular function are concerned. 